\title{
Evaluating the Introduction of a National Minimum Wage: Evidence from a New Survey of Firms in Ireland
}

\section{Donal O’Neill — Brian Nolan - James Williams}

Abstract. In April 2000 the Irish government introduced a national minimum wage of IR $£ 4.40$ (€5.58) an hour. We use data from a specifically designed survey of firms to estimate the employment effects of this change. Employment growth among firms with low-wage workers prior to the legislation was no different from that of firms not affected by the legislation. A more refined measure of the minimum wage, however, suggests that the legislation may have had a negative effect on employment for the small number of firms most severely affected by the legislation. However, the size of these effects is relatively modest.

\section{Introduction}

While there is still debate on the effect of minimum wage laws on employment, a growing number of studies have found effects that are clustered around zero (Brown, 1999). Much of this research, however, is based on either US studies (e.g. Card and Krueger, 1995,

Donal O'Neill (author for correspondence), Economics Department, NUI Maynooth, Maynooth, Co. Kildare, Ireland and Research Associate, NIRSA, NUI Maynooth. E-mail: donal.oneill@nuim.ie.

Brian Nolan - James Williams, The Economic and Social Research Institute, 4 Burlington Road, Dublin.

We would like to thank Paul Devereux, Aedin Doris, John Kennan, Alan Manning, Olive Sweetman and seminar participants at NUI Maynooth, the North American Summer Meetings of the Econometric Society (Maryland, USA), the Annual Conference of the Royal Economic Society (Warwick, UK), the Annual Conference of the Irish Economics Association (Mullingar, Ireland) and the Meeting of the Applied Econometric Association (Brussels, Belgium) for helpful suggestions on earlier drafts of this paper. We are also grateful to an anonymous referee for extensive comments. 
2000; Neumark and Wascher, 2000) or UK research (e.g. Dickens et al., 1999; Machin and Manning, 1996; Machin et al., 2003; Stewart, 2004). In this paper we provide additional empirical evidence on the labour market effects of minimum wage legislation by examining the introduction of a national minimum wage (NMW) in Ireland in April 2000. Prior to April 2000, minimum wages in Ireland were set by Joint Labour Committees (JLCs). However, the wages specified in these agreements were often quite low and covered less than a quarter of the workforce. Furthermore, the level of enforcement was quite weak. On 1 April 2000 the Irish government introduced a NMW of IR£4.40 (€5.58) per hour for all adult workers aged 18 years or older.

In this paper we evaluate the impact of this legislation on wages and employment using data collected from a new survey of firms carried out before and after the introduction of the NMW. The panel survey contains detailed information on the employment structures and work practices of firms, as well as subjective questions relating to the company's attitude towards minimum wage laws. Our analysis suggests that the minimum wage legislation had little effect on the probability of firms closing down. Furthermore, employment growth among firms with low-wage workers prior to the legislation was no different from that of firms not affected by the law. However, these simple comparisons fail to take into account the significant wage growth that occurred in Ireland during this period. In some firms, low-wage workers would have experienced a wage increase even in the absence of the legislation. When we adjust our analysis to account for this we find lower employment growth within the small number of firms most severely affected by the legislation. However, the implied elasticity of labour demand is relatively small given the unskilled nature of the workers involved.

\section{The national minimum wage in Ireland: a new survey of firms}

Between 1995 and 2000 real income in Ireland grew by approximately 10 per cent per year; the corresponding figure for the entire EU was only 2.6 per cent. Over this same period the unemployment rate in Ireland fell from 12.3 per cent to 4.3 per cent and average hourly industrial earnings increased by 25 per cent. It was against this background of substantial economic growth that the Minimum Wage Commission was set up to oversee the introduction of a 
national minimum wage in Ireland. The Report of the National Minimum Wage Commission (1998, pp. 59-60) recommended that:

The initial rate for the national minimum wage should be set at around two thirds of median earnings ... [noting that]... in today's terms, two thirds of median earnings would represent IR $£ 4.40$ per hour.

A separate rate for employees under 18 years of age, set at 70 per cent of the full rate, was also recommended. By the time it was introduced in April 2000 the minimum wage rate of IR $£ 4.40$ (€5.58) corresponded to approximately half of the median wage rate.

To examine the consequences of this legislation on labour market outcomes we conducted a new survey of Irish firms. ${ }^{1}$ During the last quarter of 1998, 2,330 establishments were asked to complete a questionnaire designed to collect details on current employment size; employment structures by hourly pay rates; and the age, gender and full- or part-time composition of their workforce in the 12 months preceding the survey. In the first instance, an owner or director of the company was contacted in relation to the survey. If necessary they could pass the survey on to the individual with responsibility for, and knowledge of, the employment structure of the firm. ${ }^{2}$ Approximately 52 per cent of the questionnaires were completed by an owner or director of the company; 37 per cent by a human resources manager or equivalent; and only 11 per cent were completed by lower grade staff. In total, 1,064 questionnaires were completed successfully ${ }^{3}$ and the data provided describe the work practices and employment structure of firms 12-14 months prior to the introduction of the minimum wage.

A detailed description of these data is given in the Data appendix. Tables A1-A7 summarize the characteristics of the workers and firms within the sample. The Appendix also provides a detailed classification of minimum wage workers based on our initial survey. Our survey did not collect individual wage data; rather, firms were asked to classify workers according to the wage bands given in Tables A1 and A2. At the time the legislation was proposed 21 per cent of all private-sector employees in the survey were earning IR $£ 4.50$ or less, with part-time workers over-represented among the low paid. Table A2 provides a more detailed breakdown of the incidence of low pay. The first column indicates that approximately 13 per cent of private-sector employees were being paid between IR $£ 4.00$ and IR $£ 4.50$ an hour, approximately 7 per cent received an 
hourly wage between IR $£ 3.00$ and IR£3.99, while only 1.5 per cent of private-sector employees received an hourly wage of less than IR£3.00. The second column shows the composition of the low paid by wage category. We see that 60 per cent of those earning less than IR $£ 4.50$ an hour had an hourly wage between IR $£ 4.00$ and IR $£ 4.50$. Almost one-third earned between IR $£ 3.00$ and IR $£ 4.00$ an hour, while only 7 per cent of low-paid workers earned less than IR $£ 3.00$ an hour.

The results in Tables A3-A6 are much as expected. Women accounted for approximately 57 per cent of those below IR£4.50. Since women represented a minority of all employees, this means they faced a greater risk of being affected by the minimum wage legislation. Over 80 per cent of those aged under 18 were below IR£4.50. The percentage below this cut-off was still relatively high for the 19-25 age group (approximately 34 per cent), but then fell sharply to 11 per cent for older workers. Table A5 shows that three occupations were particularly vulnerable to low pay: sales, personal services, and labourers. In each of these occupations at least onethird of workers were paid less than IR $£ 4.50$ an hour, with the figure being as high as two-thirds in personal services. The first two of these occupations accounted for 56 per cent of all low-paid employees, despite accounting for only 21 per cent of the total workforce. Production operatives also accounted for a substantial proportion of low-paid workers; however, the proportion of these workers in the low-pay category was in line with their representation among all employees. Finally, Table A6 provides a breakdown of low pay by industry. Several important features emerge from this analysis. There were three sectors within which workers faced a relatively high probability of being low paid; 33 per cent of all workers in the textiles and apparel industries were paid less than IR $£ 4.50$ an hour, with the corresponding figures in the retail sector and the hotel, restaurant and bar sectors being 39 per cent and 50 per cent, respectively. The final column of the table shows that between them the latter two sectors accounted for 57 per cent of low-paid workers. Workers in the textile and apparel sector made up a relatively small proportion of those being paid less than IR $£ 4.50$ because they accounted for only 2 per cent of the total number of employees.

In the last quarter of 2000 we conducted a follow-up survey of these establishments in order to examine firm-level responses to the minimum wage. Attempts were made to contact each of the firms in the original survey. As well as these firms, a number of additional firms were also surveyed. In total, 1,045 firms responded to the 
second survey, of which 587 contained employment and wage data from both surveys. ${ }^{4}$ In addition, we identified 50 firms that had gone out of business by the time of the second sweep, bringing the total number matched at the two surveys up to $637 .{ }^{5}$ Since the NMW was introduced in April 2000, the data from the second survey reflect employment structures approximately 6 months after the minimum wage legislation was enacted. The matched firms are used to assess the impact of the minimum wage on labour market variables. Summary statistics for the full sample and the matched sample are given in Table A7 of the Data appendix and are very similar across both samples. We have also estimated a probit model for participation in the second survey. The $p$-value of the minimum wage variable was 0.45 . This suggests that, in the context of our minimum wage analysis, attrition across waves can be viewed as random. Thus, while non-response unfortunately reduces our sample sizes and consequently the precision of our estimators, it is less likely to bias our estimation procedure.

In designing the survey we have tried to carefully address criticisms aimed at earlier 'before-and-after' studies of the US minimum wage. It has been noted by a number of researchers (see, for example, Brown, 1999, p. 2,132) that before-and-after comparisons may be affected by the timing of these comparisons. It is quite common for potential minimum wage legislation to be in the public domain for some time prior to being passed. If this is the case then some firms, anticipating its introduction, may begin to make gradual changes to their employment structure even before the legislation is enacted. Studies that use employment levels before the minimum wage law is passed as the benchmark level of employment may therefore have already missed some of the employment response. To account for this we included a series of questions at the end of the first survey examining the employers' awareness of the minimum wage and whether they had already taken steps to prepare for a situation where a minimum wage operates. Although 80 per cent of firms reported having heard of the proposed minimum wage, less than one-third knew the rate at which it was to be introduced. Furthermore, only 29 per cent of these firms knew the year it was to be introduced ( 20 per cent answered the wrong year and the remaining 51 per cent said they did not know). Finally, when asked whether their company had taken any steps to prepare for the minimum wage, only 13 per cent of all firms said that they had and most of these firms simply noted that they already paid above the minimum wage. We obtained similar proportions when 
we restricted our sample to firms that had minimum wage workers at the time of the first survey. Based on these data we are confident that our first-wave data provide an appropriate pre-legislation benchmark for the firms in our survey.

It has also been suggested that measurement error in the employment data may distort the results from surveys of this kind. ${ }^{6}$ There are a number of reasons why we think this is less likely for our data. Firstly, all our questionnaires were completed on a personally administered basis that involved an interviewer paying a visit to each respondent and completing the instrument on site. Secondly, while the employment data in our survey come from a question asking ' . . . the total number of persons currently engaged in your company, on a full-time and part-time basis', the respondent was later asked to classify the staff on the basis of pay, age, gender and occupation. At each stage the interviewer was instructed to check that the totals from these classifications matched the response to the initial employment question. Where inconsistencies became apparent these were resolved by telephone follow-up with the respondent. These consistency checks increase the reliability of our employment data and reduce the likelihood of measurement error. Finally, we attempted to ensure that the same individual filled in the questionnaire in both waves of the survey.

To examine the issue of measurement error further we follow Neumark and Wascher (2000). They argue that classical measurement error that is uncorrelated over time should manifest itself through a relatively low correlation in employment levels within firms across the two waves of the data. They report a correlation of 0.52 using survey data compared with a correlation of 0.81 using payroll data. Figure 1, shows a plot of wave 2 versus wave 1 employment for the matched firms in our sample. The estimated correlation is 0.92 , which is higher than either of the samples considered by Neumark and Wascher.,

\section{Employment effects of the minimum wage}

The first wave of our survey shows that approximately 50 per cent of the firms sampled had at least one worker earning less than the proposed minimum in the year prior to the introduction of the law. As noted above, these workers constituted 21 per cent of all privatesector employees in the firm survey, with approximately 13 per cent of private-sector employees being paid between IR $£ 4.00$ and 
Figure 1. Employment correlation within firms across the two waves of the survey

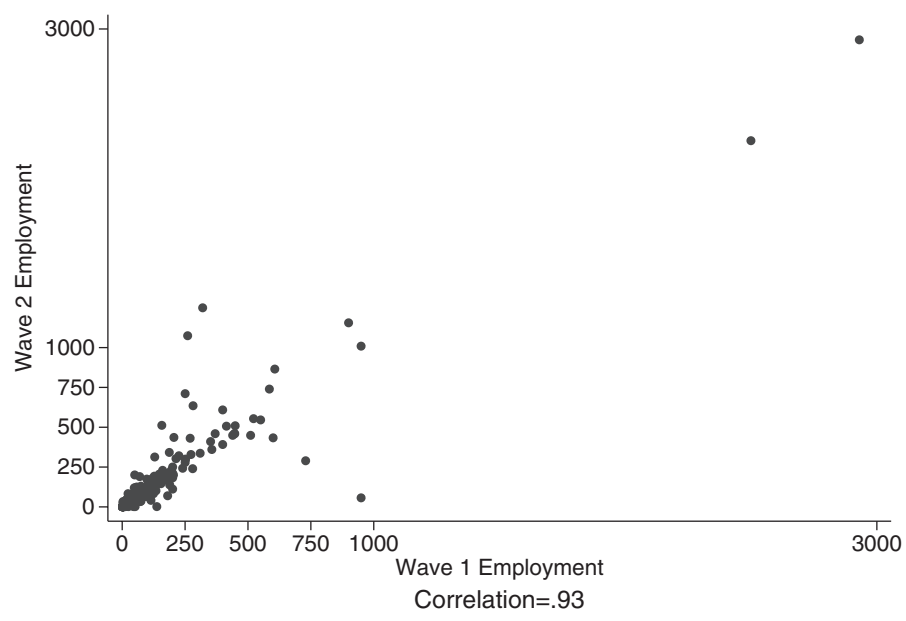

IR£4.50 an hour and approximately 8.5 per cent receiving an hourly wage less than IR£3.99. The lack of individual wage data makes it difficult to run wage regressions to establish the impact of the minimum wage on firms' wages. Nevertheless using the second wave of our survey we can establish that by the end of 2000 only 24 per cent of firms had at least one worker receiving IR $£ 4.50$ or less and these workers constituted only 4 per cent of the employees in the firm survey. Only approximately 1 per cent of all employees earned less than IR£3.99 by the end of 2000 . We also asked firms to indicate the approximate percentage increase in their wage bill resulting directly from the legislation -76 per cent of the firms that responded stated that the legislation had no effect on their wage bill. As expected, firms with a larger proportion of minimum wage workers at the time of the legislation were significantly more likely to cite increased labour costs. The average increase in labour costs among the 24 per cent of affected firms was approximately 8.6 per cent. This is a relatively large increase in wages and suggests that for those firms that were affected, the minimum wage may have had a significant bite.

In the second survey we also asked firms to respond to two questions related to wage spillovers higher up the wage distributions. The questions were as follows: 
Q.32 When the minimum wage was introduced did you have to increase the hourly rates of higher grade staff to maintain pay differentials?

Yes $\square_{1}$ No $\square_{2}$

Q.33 I would like you to think in terms of those workers who were above the minimum wage when it was introduced. Approximately what percentage of your workforce which was above the minimum wage received an increase in hourly pay rates as a result of restoring pay differentials?

per cent

In total, 18 per cent of firms acknowledged some spillover effects. The extent of spillover among these firms was quite large: on average, 50 per cent of the high-wage workers in these firms were reported to have received wage increases in order to maintain pay differentials. The international evidence on wage spillovers is mixed. Teulings (2003) reports large spillover effects in the USA, with the negative effect of minimum wage reductions affecting all wages up to the average wage. Dickens and Manning (2004a, b), on the other hand, found little evidence of spillovers arising from the introduction of the national minimum wage in the UK. Each of these studies requires identifying assumptions on the evolution of the underlying wage distribution. In contrast, our estimates are based on direct responses of firms to questions concerning the degree of wage spillover. Ignoring measurement, which may affect both types of studies, our approach gives a more accurate measure of the number of workers affected by spillovers. Unfortunately, we cannot use our data to identify the contribution of spillovers to the overall wage distribution. We return to the issue of spillovers later in the paper.

To begin examining the employment effects of these wage changes we look at firms that had gone out of business by the time of the second survey. Although this is a rather extreme form of employment change, the possibility that firms would be forced out of business as a result of the legislation was presented as a real threat by opponents of the minimum wage prior to its introduction. To examine this possibility, Table 1 classifies firms according to their business status at the end of 2000 and also according to their sales and profit activity during 1998. Not surprisingly, we see that firms that went out of business are over-represented among firms that 
Table 1. Firms that participated in the 1998 survey cross-classified according to the volume of their business/level of profits in the 12 months preceding the 1998 survey and business status in 2000

\begin{tabular}{lccc}
\hline Trends in $\mathbf{1 9 9 8}$ & $\begin{array}{c}\text { In business } \\
\text { in } \mathbf{2 0 0 0}(\mathbf{\%})\end{array}$ & $\begin{array}{c}\text { Out of business } \\
\text { in } \mathbf{2 0 0 0}(\mathbf{\%})\end{array}$ & All firms (\%) \\
\hline Business volumes & & & \\
$\quad$ Increased & 55.01 & 31.85 & 53.34 \\
Stayed the same & 38.15 & 36.32 & 37.94 \\
Decreased & 6.84 & 31.83 & 9.72 \\
Total & 100.0 & 100.0 & 100.0 \\
Profit levels & & & \\
Substantial loss & 0.15 & 14.27 & 1.78 \\
Moderate loss & 4.08 & 15.26 & 5.37 \\
Broke even & 21.01 & 31.38 & 22.21 \\
Moderate profit & 69.33 & 39.12 & 65.84 \\
Substantial profit & 5.43 & 0.0 & 4.8 \\
Total & 100.0 & 100.0 & 100.0 \\
\hline
\end{tabular}

Table 2. Firms that participated in the 1998 survey cross-classified according to the percentage of employees in 1998 who were below an hourly basic pay of IR£4.50 (€5.71) and business status in 2000

\begin{tabular}{lccc}
\hline $\begin{array}{l}\text { Percentage below IR£4.50 } \\
(\mathbf{€ 5 . 7 1 )} \text { an hour in } \mathbf{1 9 9 8}\end{array}$ & $\begin{array}{c}\text { In business } \\
\text { in } \mathbf{2 0 0 0}(\mathbf{\%})\end{array}$ & $\begin{array}{c}\text { Out of business } \\
\text { in } \mathbf{2 0 0 0}(\mathbf{\%})\end{array}$ & $\begin{array}{c}\text { All firms } \\
\mathbf{( \% )}\end{array}$ \\
\hline None & 52.82 & 58.89 & 53.51 \\
Less than 15\% & 4.95 & 1.1 & 4.51 \\
15\% or more & 42.23 & 40 & 41.98 \\
Total & 100.0 & 100.0 & 100.0 \\
\hline
\end{tabular}

experienced both sales and profit difficulties in the years before the survey. However, of more interest to us is the extent to which the closure decision was affected by the minimum wage legislation. Table 2 classifies these firms according to the wage structure of their employment force in 1998. These figures show that firms that had gone out of business by the time of the second survey tended to be disproportionately high-wage firms and are under-represented among firms employing a large number of minimum wage workers. This is not what one would expect if the minimum wage were forcing firms to shut down. We have also estimated a probit model 
for the likelihood of going out of business which, as well as including controls for wage structure and profit status, also controls for a range of other firm characteristics. As expected, firms that were performing poorly prior to the survey were significantly more likely to close down. However, the estimated coefficient on the minimum wage indicator was statistically insignificant $(p=0.39)$. Our results are consistent with those reported recently on the impact of the UK NMW on care home closures (Machin and Wilson, 2004).

Although the minimum wage may not have resulted in many firms going out of business it may still have caused employment reductions among those firms that remained in business. On average, employment in all firms increased by approximately 18 per cent over this period $;{ }^{9}$ however, the median increase in employment was only 3 per cent, and 30 per cent of the firms experienced a decline in employment. To examine the employment effects of the wage changes for these firms we relate employment growth over this period to measures of the effective bite of the minimum wage. We follow Machin et al. (2003) and estimate the following equation:

$$
\% \Delta\left(N_{i t}\right)=\beta_{0}+\beta_{1} \operatorname{Min} W_{i, t-1}+\beta_{2} X_{i t-1}+e_{i t},
$$

where $\% \Delta\left(N_{i t}\right)$ measures the percentage change in employment between 1998 and 2000, Min $W$ measures the effective bite of the minimum wage and $X$ is a vector of controls for observable firm characteristics. To estimate this equation we needed to construct a measure of $\operatorname{Min} W$. Initially we use the proportion of the firm's labour force that was below the NMW prior to its introduction (we denote this by PropLow98). The results of estimating equation [1], using only this measure as a control, are given in the first column of Table 3. We see that this measure of the minimum wage bite is not significantly related to employment growth. This is consistent with the findings of Card and Krueger $(1995,2000)$ and Machin and Manning (1994, 1996).

In the above model, identification is achieved by comparing firms with minimum wage workers with firms without these workers. It is likely that these firms may have experienced different employment patterns even without the legislation. Failure to control for these differences could distort any minimum wage impact. Our surveys allow us to identify some firm characteristics that may act as useful control variables. The controls available include whether the firm was Irish or foreign owned (Irish); whether the firm exported or not (Export); an indicator of the profitability of the firm in the year 
Table 3. The impact of minimum wages on employment (dependent variable - percentage change in employment from 1998 to 2000; White's robust standard errors are reported in parentheses)

\begin{tabular}{lcc}
\hline Explanatory variable & $\mathbf{( 1 )}$ & $\mathbf{( 2 )}$ \\
\hline Constant & $0.16^{* *}$ & $0.27^{*}$ \\
PropLow98 & $(0.04)$ & $(0.16)$ \\
& 0.0002 & 0.0002 \\
Irish & $(0.001)$ & $(0.001)$ \\
& & -0.12 \\
Export & & $(0.10)$ \\
Profit & & 0.007 \\
Union & & $0.07)$ \\
Wage Bill & & $0.10^{*}$ \\
TotEmp98 & & $-0.06)$ \\
& & $(0.07)$ \\
$R^{2}$ & & -0.002 \\
Sample size & $-0.002)$ \\
\end{tabular}

* Significant at the 10 per cent level; ** significant at the 5 per cent level.

prior to the minimum wage (Profit); an indicator variable denoting whether or not at least 50 per cent of the firm's non-managerial employees were in a trade union (Union); as well as the percentage of the company's total operating costs that are accounted for by its wage bill (Wage Bill). We also included the firm's initial employment level (TotEmp98) as a regressor. Summary statistics for these variables are given in the Appendix. ${ }^{10}$ The results from this specification are given in column (2) of Table $3 .{ }^{11}$ Including the additional controls has little effect on the minimum wage estimates; the minimum wage effect is still small and insignificant.

An alternative way of achieving identification is to focus only on firms with minimum wage workers and to use variations in the proportion of the labour force below the minimum wage to identify the effect for this sample. While this reduces the number of observations available, it should also reduce the unobserved heterogeneity in the sample. The results from this exercise are given in Table 4. 
Table 4. The impact of minimum wages on employment (minimum wage firms only) (dependent variable - percentage changes in employment from 1998 to 2000; White's robust standard errors appear in parentheses)

\begin{tabular}{lcc}
\hline Explanatory variable & $(\mathbf{1})$ & $(\mathbf{2})$ \\
\hline Constant & $0.13^{* *}$ & 0.27 \\
PropLow98 & $(0.08)$ & $(0.24)$ \\
& 0.0006 & 0.0008 \\
Irish & $(0.001)$ & $(0.002)$ \\
& & $-0.20^{*}$ \\
Export & & $(0.11)$ \\
Profit & & -0.01 \\
Union & & $(0.08)$ \\
Wage Bill & & $0.14^{* *}$ \\
TotEmp98 & & $0.07)$ \\
$R^{2}$ & - & $-0.10)$ \\
Sample size & 230 & $(0.003)$ \\
\hline
\end{tabular}

* Significant at the 10 per cent level; ** significant at the 5 per cent level.

Restricting the sample only to minimum wage firms makes little difference to our results; again, it appears as though the minimum wage had little effect on employment growth.

While the results so far suggest that the minimum wage had little effect on employment changes, we need to be careful in interpreting these findings. We noted above that approximately 20 per cent of Irish employees were receiving less than the minimum wage in the year prior to the introduction of the NMW. In the analysis so far this group has formed the basis of our treatment group. However, a criticism that has often been levelled at these types of studies is their inability to distinguish between the potential and the actual bite of the minimum wage (Deere et al., 1996). It is reasonable to assume that some of the workers in receipt of wages below the minimum wage in 1998 would have received a wage increase by 2000 in any case. It would not be surprising to find that the legislation had little effect on these workers even though they are recorded in our data as minimum wage workers. As noted above, 
this is likely to be a serious issue in the Irish context. While restrained wage growth was a notable feature of the Irish labour market for much of the 1990s, the labour market tightened significantly in the late 1990s. Employment grew by over 6 per cent in 1999 and the unemployment rate fell below 5 per cent. This growth continued in 2000 with an additional 75,000 people in work that year. The rise in employment was accompanied by a marked decline in unemployment and long-term unemployment: the long-term unemployment rate more than halved since the beginning of 1998, reaching just 1.7 per cent by the first quarter of 2000 .

Evidence on earnings trends across a broad range of occupations and sectors shows that wage inflation began to accelerate significantly from 1997 onwards. Of particular concern in this study is the growth rate in wages between the last quarter of 1998, when our first survey was conducted, and April 2000, when the minimum wage was introduced. Data on industrial earnings indicate that average hourly earnings increased by 8.5 per cent over this period. The average hourly earnings of unskilled and semi-skilled operatives, in the construction industry, increased by over 15 per cent. In the services sector, average weekly earnings over this same period were up 18 per cent in distribution; 24 per cent in the retail trade; and 12 per cent in the business services sector. Given these circumstances, it seems reasonable that the 50 per cent of firms identified as having a minimum wage worker in the 1998 survey overestimates the actual number of firms affected by the legislation.

To account for the natural growth in wages we asked firms affected by the minimum wage the following question:

\section{Q.31 Given trends in the labour market in Ireland over the last year, do you think that you would have had to increase wage rates anyway up to the minimum level set out in the minimum wage?}

Of the second-wave firms that reported having minimum wage workers at the time the law was introduced, 84 per cent said that they would have increased wages in any case. This is in keeping with the rapid economy-wide increases in wages outlined in the earlier paragraph. To allow for this in our analysis we create a new minimum wage variable (EffectiveMW). This takes the value 1 only if the firm reported in 2001 that it had workers affected by the legislation and would not have increased wages were it not for the legislation. Using these criteria, only 4 per cent of firms (38 firms) were actually directly affected by the minimum wage legislation. 
One immediate concern that arises in this context is whether it is plausible that only 4 per cent of firms were directly affected by the legislation. While it is difficult to address this issue directly with our data, we can get some idea of the likely magnitudes involved by combining our estimates for average wage growth over this period with information on the extent to which wages in these firms fell below the minimum. We noted above that average wage growth of unskilled and semi-skilled workers ranged between 15 per cent and 24 per cent over this period. With this wage growth, say 20 per cent on average, workers who had been earning IR£3.66 in the first survey would have had their wage exceed the minimum by the time of the legislation. Although our survey does not contain individual data on wages, it does allow us to classify low-wage workers into three categories: those initially earning between IR£4.00 and IR $£$ 4.50; those earning between IR $£ 3.00$ and IR $£ 4.00$; and those earning less than IR£3.00. Given the above wage growth, it seems very likely that any worker in the first category in 1998 would no longer be classified as a minimum wage worker in 2001. Of the 50 per cent of firms that initially reported having workers in the minimum wage category, almost half had workers in the first category only. Excluding these firms from the minimum wage group reduces the proportion of firms affected from 50 per cent to 28 per cent. However, even this figure is likely to overstate the number of firms affected, since in some of the remaining firms the vast majority of workers, though not all, were in the IR£4.00-4.50 category. It may also be reasonable to assume that a significant proportion of workers originally receiving between IR $£ 3.00$ and IR $£ 4.00$ would also have had their wages rise to above the minimum wage. If we make the stronger assumption that only workers that were initially in the lowest wage category (less than IR£3.00 an hour) would have been affected when the legislation was introduced, then the proportion of firms affected falls to 8.7 per cent. Thus while our new effective minimum wage measure may understate the proportion of firms affected by the legislation, it is likely to provide a more plausible measure of those affected than the initial uncorrected proportion.

To gain a better understanding of the nature of these affected firms, Panel A of Table 5 summarizes average and median employment levels in each of three groups for both 1998 and 2000. The first column refers to the entire sample, the second refers to those firms that had minimum wage workers in 1998 (the basis for the earlier estimates) and the third column refers to those firms that 
Table 5. Characteristics of firms classified by exposure to the minimum wage legislation (standard errors appear in parentheses)

\section{Firms with minimum \\ wage workers in first \\ sweep (PropLow98 > 0)}

Variable

All firms

Firms constrained by

the legislation

(EffectiveMW)

\section{Panel A}

Average employment levels in 1998

Average employment level in 2000

Median employment levels in 1998

Median employment levels in 2000

Panel B

Average proportion of firms with some workers earning less than IR£4.00 (€5.08) in 1998

Average number of workers per firm affected by the legislation in 2000

Average proportion of workers per firm at IR $£ 4.50$ (€5.71) after legislation

Average percentage increase in wage bill as a result of legislation

Proportion of firms affected by wage spillovers

Average proportion of workers per firm affected by wage spillovers (affected firms only) ${ }^{a}$

$\begin{array}{lll}66 & 58 & 90 \\ 82 & 64 & 94 \\ 20 & 25 & 17 \\ 22 & 28 & 17\end{array}$

$28 \%$

$56 \%$

4

$(0.58)$

0.06

7.3

(1.3)

0.10

$(0.005) \quad(0.01)$

$3.7 \%$

$1.99 \%$

(0.39)

$17.51 \%$

$29.19 \%$

$54.45 \%$

Notes: ${ }^{a}$ The spillover calculations are based on firms' responses to two direct questions on wage spillovers asked in our survey. The first asked: 'When the minimum wage was introduced did you have to increase the hourly rate of higher grade staff to maintain pay differentials?' If yes, the firms were then asked: 'What percentage of the workforce which was above the minimum wage received an increase in hourly pay rates as a result of restoring pay differentials?' 
reported having workers affected by the legislation in 2000 and that would not have raised wages were it not for the legislation. We refer to these latter firms as 'Effective Minimum Wage Firms'. The large differences between the mean and median figures, within a group, reflect the fact that employment in these firms is highly skewed to the right. Comparing employment levels over time reveals substantial employment growth for the first two classes of firms, with much more modest growth for the affected firms.

Before looking at these employment changes in more detail, Panel B of Table 5 highlights some of the other differences between the affected firms and the other firms in the sample. The table classifies firms by other measures likely to be associated with exposure to the minimum wage legislation. These include the proportion of firms with at least one worker earning less than IR£4.00 in 1998; the average number of workers affected by the legislation in 2000; the proportion of workers currently being paid at or below the minimum wage (a spike measure commonly used in minimum wage studies); the increase in the wage bill associated with the minimum wage; and the probability and extent of wage spillovers as a result of the minimum wage legislation. ${ }^{12}$ Firms that would not have increased wages in the absence of the legislation had a greater number of workers actually affected by the legislation. They also had a larger proportion of their current workforce located at or below the minimum wage and had larger increases in their wage bill as a result of the minimum wage. We can also examine the issue of wage spillovers higher up the distribution using the spillover questions discussed above. The last two rows of Table 5 summarize responses to these questions. Firms that reported being most affected by the legislation were 60 per cent more likely to be affected by spillovers and, once affected, also had to raise wages for a larger proportion of the non-minimum wage workforce. All of these comparisons reinforce our maintained hypothesis that the firms that we identify as 'Effective Minimum Wage Firms' are precisely those firms most affected by the legislation.

To examine the employment effects of the legislation on these firms we re-estimated equation [1] using the redefined measure of the minimum wage bite. The results from this analysis are presented in the first column of Table $6 .{ }^{13}$ None of the estimates on the control variables change much as a result of redefining the minimum wage variable. However, there is a striking change in the estimated minimum wage effect. Whereas in previous specifications the minimum wage variable was small and insignificant, it is now 
Table 6. The impact of the minimum wage on employment using a selfreported measure of minimum wage (dependent variable percentage change in employment from 1998 to 2000; standard errors appear in parentheses)

\begin{tabular}{lccc}
\hline Explanatory variable & $(\mathbf{1}) \mathbf{O L S}^{\mathrm{a}}$ & $\begin{array}{c}\text { (2) Median } \\
\text { regression }^{\mathrm{b}}\end{array}$ & $\begin{array}{c}\text { (3) Robust } \\
\text { regression }\end{array}$ \\
\hline Constant & $0.28^{*}$ & 0.07 & 0.08 \\
EffectiveMW & $(0.15)$ & $(0.05)$ & $(0.07)$ \\
Irish & $-0.29^{* *}$ & $-0.19^{* *}$ & $-0.20^{* *}$ \\
& $(0.08)$ & $(0.06)$ & $(0.08)$ \\
Export & -0.11 & -0.05 & -0.04 \\
& $(0.11)$ & $(0.04)$ & $(0.05)$ \\
Profit & 0.007 & 0.01 & 0.002 \\
& $(0.07)$ & $(0.02)$ & $(0.03)$ \\
Union & 0.1 & $0.09 * *$ & 0.06 \\
& $(0.06)$ & $(0.02)$ & $(0.04)$ \\
Wage Bill & -0.02 & $-0.08^{* *}$ & -0.02 \\
& $(0.06)$ & $(0.03)$ & $(0.04)$ \\
TotEmp99 & -0.002 & -0.001 & -0.001 \\
& $(0.002)$ & $(0.001)$ & $(0.001)$ \\
Sample size & -0.0001 & 0.0001 & 0.0001 \\
& $(0.0001)$ & $(0.0001)$ & $(0.0001)$ \\
\hline
\end{tabular}

Notes: * Significant at the 10 per cent level; ** significant at the 5 per cent level.

${ }^{a} t$-stats based on White's robust standard errors.

${ }^{\mathrm{b}} t$-stats calculated using bootstrap procedure.

statistically significant and negative: firms that had workers subjected to the minimum wage legislation and that would not have increased their wages fully were it not for the legislation have significantly smaller increases in employment than other firms. For instance, the median regression suggests that on average the growth rate in employment was 19 percentage points less in the affected firms than it was in the other firms.

This is the first evidence we find of a negative minimum wage effect. It is important to realize that when we restrict attention to firms that have valid data on each of the control variables we are left with relatively few firms that report that they were affected by the legislation, as we have defined it. In this context it is essential that we examine the robustness of our findings. We check the robustness of our results using two alternative estimators. Firstly, we re-estimate the model using a median regression estimator, 
rather than OLS. As the median estimator minimizes the sum of the absolute value of the residuals it is less sensitive to outliers than the OLS estimator. Secondly, we use the two-stage robust estimator suggested by $\mathrm{Li}$ (1985). The results of the median regression are given in the second column of Table 6 , while the results of the robust regression are given in the third column. The results from both these approaches are very similar: although these estimators cause the minimum wage estimate to fall, the significantly negative effect identified in the linear regression model is still apparent even when we control for outliers.

If we are to be confident about these estimates it is important we know that the effect that we are measuring captures a response to the minimum wage and not some other shock. We noted in Table 5 that the firms classified as minimum wage firms were also more likely to exhibit greater response to the minimum wage in terms of the direct wage bill and spillovers. However, using this self-reported measure of minimum wage bite may not be valid if there is a relationship between employment changes and a firm's willingness to increase wages irrespective of any minimum wage legislation. Perhaps the estimator is simply picking up the fact that firms that perform poorly are more likely to be low wage and also constrained when it comes to increasing wages; or that firms that performed poorly are simply using the minimum wage as an ex post justification of their failures. A traditional approach to correcting for this type of problem would be to instrument the minimum wage variable. However, it is difficult to construct satisfactory instruments in this example - that is a variable that is correlated with the selfreported minimum wage bite but uncorrelated with the unobserved measures affecting a firm's performance. We therefore seek an alternative approach. If our redefined minimum wage variable is simply a proxy for firms with poor 'employment-creating characteristics' or firms that performed poorly for reasons other than the minimum wage then we might expect to see these firms perform poorly even in periods where there was no minimum wage legislation. Since the employment records in our survey are limited to two observations, one before and one after the minimum wage legislation, we cannot calculate actual employment changes for the firms in other periods. However, in the first wave of our survey we did ask firms to record 'if compared to the same period in 1997 their labour force had increased, stayed the same or fallen'. This provides us with a selfreported measure of employment changes from 1997 to 1998, 2 years prior to the minimum wage legislation. If the self-reported 
Table 7. The relationship between self-reported minimum wage bite and employment changes for 1997/98 and 1998-2000 (standard errors appear in parentheses)

\begin{tabular}{lcc}
\hline Explanatory variable & (1) $\mathbf{1 9 9 7 / 9 8}$ & (2) $\mathbf{1 9 9 8 - 2 0 0 0}$ \\
\hline Constant & $-1.38^{* *}$ & $-0.54^{* *}$ \\
& $(0.08)$ & $(0.06)$ \\
EffectiveMW & 0.35 & $0.67^{* *}$ \\
& $(0.35)$ & $(0.29)$ \\
Sample size & 574 & 574
\end{tabular}

* Significant at the 10 per cent level; ** significant at the 5 per cent level.

minimum wage variable is proxying for firms with unfavourable unobserved characteristics then we should expect to see these firms also experiencing relative employment falls in this period also. To determine whether this is so we constructed a binary variable taking the value 1 if employment fell between 1997 and 1998 and zero otherwise. We then estimated the relationship between this binary measure of employment change and the self-reported minimum wage bite from the second wave of the survey. The results are presented in column (1) of Table 7. While the self-reported minimum wage variable does increase the probability of observing employment declines from 1997 to 1998, it is not statistically significant: employment growth in earlier years, for firms that said they would not have increased wages were it not for the minimum wage, is not significantly different from that of other firms.

One could argue that using the binary measure of employment changes reduces the variation in the employment variable and that this is responsible for the insignificant effect in the earlier period. To check this we created a similar binary indicator for the 1998-2000 employment changes and re-estimated the minimum wage equation using this as the dependent variable. The results are given in column (2) of Table 7 . The results clearly show that, even when a binary indicator of employment decline is used to measure employment changes, the self-reported minimum wage bite significantly increases the probability of observing an employment decline after the legislation. Part of the differences between the results in the two periods reflects the relatively large standard error in the earlier period. Nevertheless, while acknowledging the coefficient in the first model is estimated imprecisely, the estimated coefficient in the later period is over twice as large as that estimated for the period 
without the legislation. Although these results do not provide a definitive case for our measure, the fact that the pre-legislation effects of our redefined minimum wage variable are statistically insignificant and much smaller in magnitude than the later effects is at least consistent with the view that our measure is more than just a proxy for unobserved firm-level characteristics. ${ }^{14}$

A final important check as to the appropriate interpretation of our minimum wage estimate can be based on the change in output prices that occurred over this time. If these firms were simply using the minimum wage as an ex post rationalization for poor employment growth, arising from falling demand, then we would expect output prices to fall relative to those in other firms, as the relative demand curve shifts in. However, when asked in the survey what happened to output prices over this period, firms affected by the minimum wage were more likely to indicate that output prices had risen. This is consistent with a shift in the industry supply curve due to increased costs (such as the minimum wage) rather than a reduction in demand. Thus while we are conscious of the potential limitations of our effective minimum wage measure, the fact that the firms we identify correspond to those most affected by the legislation using a number of more traditional measures of minimum wage bite; that their employment behaviour prior to the legislation was not significantly different from that of the control group; and perhaps most convincingly that output prices for these firms increased rather than declined over this period, all support the view that the employment effects we identify are minimum wage effects and not an ex post rationalization of poor performance by the firms. ${ }^{15}$

A final estimate of the impact of the minimum wage legislation on employment levels can be obtained directly from firms' responses to a question we asked in the second wave of the survey. The question was as follows:

\section{Q.36 Suppose the minimum wage had not been introduced. Do you think you would be employing: more people today than you are; the same number of people or fewer people?}

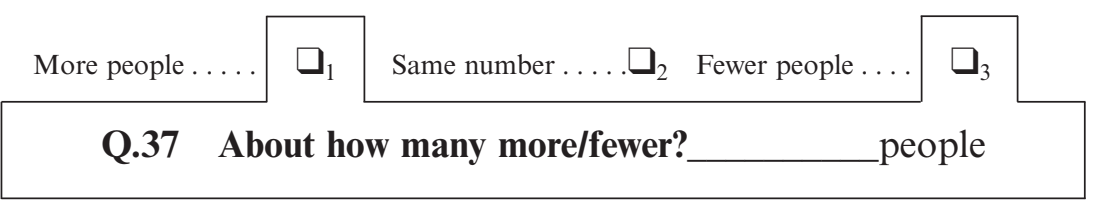


Approximately 30 per cent of affected firms answered this question positively. This provides some additional evidence of a negative employment effect. The average increase in employment across all these firms is approximately 6 per cent of their current workforce, which is somewhat lower than the 19 per cent estimate obtained from the earlier analysis.

To understand the implications of our analysis we use our data to estimate labour demand elasticities. To do this we need to know the percentage change in employment for the affected minimum wage firms as a result of the legislation $\left(\alpha_{N}\right)$, along with the percentage increase in wages associated with the legislation $\left(\alpha_{w}\right)$. The elasticity of demand can then be calculated as $\alpha_{N} / \alpha_{w}{ }^{16}$ Using firms' direct responses to the minimum wage question we obtain a reduction in employment $\left(\alpha_{N}\right)$ of 6 per cent. In order to estimate the labour demand elasticity we also need a measure of the wage change induced by the minimum wage. Machin et al. (2003) estimate this effect using a linear regression where the change in average wages in each firm is regressed on a measure of the minimum wage. Unfortunately, as noted above, the structure of our wage data makes it difficult to adopt this approach. One alternative we can use is to take the average response of our firms to the question in the second wave asking 'By approximately what percentage did the minimum wage directly increase your labour costs?' When this is adjusted for wage spillovers we find an estimated wage effect $\left(\alpha_{w}\right)$ of 12 per cent. Combining our estimates of $\alpha_{N}$ and $\alpha_{w}$ we therefore get an estimated labour demand elasticity of -0.5 . This estimate is certainly within the range of previous estimates of labour demand elasticities (Hamermesh, 1993, Ch. 3) and is quite close to the average estimates that tend to lie in the range of $[-0.6,-0.9]$ and to the estimates reported by Machin et al. (2003) of $[-0.15,-0.55]$. Indeed, in a recent survey carried out by Fuchs et al. (1998) a number of labour economists were asked to provide their best guess of the total wage elasticity of labour demand. The average (median) guess equalled -0.63 $(-0.50)$. On the other hand, there are reasons as to why we might have expected our estimate to be higher than these traditional estimates. Firstly, the employment estimate is based directly on employers' responses to a minimum wage question, which is likely to be an upper bound on the employment effect. Secondly, our experiment is driven by reductions in the price of unskilled labour, which traditionally tends to have relatively high elasticities. Taking these into account one might reasonably conclude that 
our estimates indicate a relatively modest negative response of labour demand to changes in wages arising from minimum wage legislation. ${ }^{17}$

\section{Conclusion}

This paper provides the first evaluation of the labour market consequences of the NMW introduced in Ireland in April 2000. To do this we use a panel survey of firms that were contacted both before and after the minimum wage was introduced, to obtain information on work practices and employment structure. Initial results show that employment growth among firms with low-wage workers, prior to the legislation, was not significantly different from that of firms not affected by the legislation. This is consistent with recent studies that have argued that minimum wages seem to have no adverse effects on employment. However, it has been recognized for some time now that counts of workers below the minimum wage (even when adjusted for distance from the minimum wage) may be an unsatisfactory measure of the bite of the minimum wage. Some workers initially below the minimum wage are likely to have their wages increased over time irrespective of the legislation. It seems incorrect to include these workers in the treatment group when looking at the effects of the legislation. This is likely to be a particular problem in Ireland, where wages increased significantly in the years prior to the legislation, and suggests that a partial explanation for the complete absence of a minimum wage effect in these data may be that so few firms were affected by the legislation. To allow for this we redefined the minimum wage variable to include only firms that had low-wage workers and that stated that they would not have increased wages by as much were it not for the minimum wage legislation. When we used this redefined measure of the minimum wage bite we found the negative employment and hours effects predicted by the competitive model of the labour market. Further analysis suggests that this result is not driven by unobserved firmlevel characteristics associated with employment growth and selfreported wage restraint. Although there is evidence of employment losses among the small number of firms most severely affected by the legislation, the estimated elasticity of labour demand is relatively modest in size, especially given the relatively low skill levels of the workers involved. 


\section{Data appendix}

\section{Variable definitions}

Deltaemp: percentage change in employment between 1998 and 2000.

Irish: a dummy variable taking the value 1 if the company was Irish owned.

Export: a dummy variable taking the value 1 if the company exported any part of its output.

Profit: a dummy variable taking the value 1 if the company reported a profit for the previous year.

Union: dummy variable taking the value 1 if more than 50 per cent of the firm's non-managerial employees were members of a trade union.

Wage Bill: labour costs as a percentage of total costs.

TotEmp98: firm employment level in 1998.

Table A1. Classification of private-sector employees by pay range

\begin{tabular}{lccc}
\hline Pay range & \% of all workers & $\begin{array}{c}\text { \% of full-time } \\
\text { workers }\end{array}$ & $\begin{array}{c}\text { \% of part-time } \\
\text { workers }\end{array}$ \\
\hline Less than IR£4.50 & 21 & 14 & 64 \\
IR£4.50-5.49 & 16 & 16 & 18 \\
IR£5.50-6.49 & 17 & 17 & 10 \\
More than IR£6.50 & 46 & 53 & 8 \\
\hline
\end{tabular}

Table A2. Classification of the low paid by pay range, private-sector employees

\begin{tabular}{lcc}
\hline Pay range & \% of the population & $\begin{array}{c}\text { \% of all earning } \\
\text { less than IR£4.50 }\end{array}$ \\
\hline IR $£ 4.00-4.50$ & 12.6 & 60.0 \\
IR $£ .00-3.99$ & 6.9 & 32.8 \\
Less than IR $£ .00$ an hour & 1.5 & 7.2 \\
\hline
\end{tabular}


Table A3. Classification of private-sector employees by gender

\begin{tabular}{lccc}
\hline Gender & $\begin{array}{c}\text { \% all } \\
\text { employees }\end{array}$ & $\begin{array}{c}\text { \% falling below } \\
\text { IR } \mathbf{4 . 5 0}\end{array}$ & $\begin{array}{c}\text { \% of all those } \\
\text { below IR£4.50 }\end{array}$ \\
\hline Male & 60.1 & 15.0 & 43.0 \\
Female & 39.9 & 30.4 & 57.0 \\
\hline
\end{tabular}

Table A4. Age classification of private-sector employees

\begin{tabular}{lccc}
\hline Age group & $\begin{array}{c}\text { \% of all } \\
\text { employees }\end{array}$ & $\begin{array}{c}\text { \% falling below } \\
\text { IR } \mathbf{4 . 5 0}\end{array}$ & $\begin{array}{c}\text { \% of all those } \\
\text { below IR } \mathbf{4 . 5 0}\end{array}$ \\
\hline Aged 18 or less & 4.8 & 80.4 & 18.3 \\
Aged 19-25 & 29.1 & 34.2 & 47.3 \\
Aged 26 or more & 66.1 & 11 & 34.4 \\
\hline
\end{tabular}

Table A5. Occupational classification of private-sector employees

\begin{tabular}{lccc}
\hline Occupation & $\begin{array}{c}\text { \% of all } \\
\text { employees }\end{array}$ & $\begin{array}{c}\text { \% below } \\
\text { IR } \mathbf{4} \text {.50 }\end{array}$ & $\begin{array}{c}\text { \% of all those } \\
\text { below IR£4.50 }\end{array}$ \\
\hline $\begin{array}{l}\text { Managers/proprietors } \\
\text { Engineering/science/computer/ }\end{array}$ & 15.7 & 4.5 & 3.3 \\
$\quad$ other professionals & 6.2 & 0.6 & 0.1 \\
$\begin{array}{l}\text { Engineering/science and } \\
\quad \text { computer technicians }\end{array}$ & 3.8 & 1.1 & 0.2 \\
$\begin{array}{l}\text { Clerical/secretarial } \\
\text { Skilled maintenance/skilled }\end{array}$ & 13.7 & 7.5 & 4.9 \\
$\quad$ production & 10.1 & 14.6 & 7 \\
$\begin{array}{l}\text { Production operatives } \\
\text { Transport and }\end{array}$ & 17.1 & 20.8 & 16.9 \\
$\quad$ communications & 5.9 & 8.2 & 2.3 \\
$\begin{array}{l}\text { Sales } \\
\text { Personal services }\end{array}$ & 13.3 & 49.7 & 31.4 \\
Labourers & 18.1 & 63.6 & 24.4 \\
\hline
\end{tabular}


Table A6. Industry breakdown of private-sector employees

\begin{tabular}{lccc}
\hline Sector & $\begin{array}{c}\text { \% of all } \\
\text { employees }\end{array}$ & $\begin{array}{c}\text { \% below } \\
\text { IR } £ \text { 4.50 }\end{array}$ & $\begin{array}{c}\text { \% of all those } \\
\text { below IR } £ 4.50\end{array}$ \\
\hline Building and construction & 7.7 & 9.1 & 3.3 \\
Manufacture of textiles and apparel & 2.0 & 33.2 & 3.3 \\
Other manufacturing and production & 25.8 & 9.7 & 11.8 \\
Retail & 17.0 & 38.8 & 31.3 \\
Wholesale & 5.1 & 22.5 & 5.5 \\
Prop/rent/business services & 16.4 & 10.7 & 8.3 \\
Hotels/restaurants/bars & 11.1 & 49.3 & 26 \\
Personal and other services & 14.9 & 14.9 & 10.5 \\
\hline
\end{tabular}

Table A7. Summary statistics of firm characteristics across the original sample and the matched sample

\begin{tabular}{lcccc}
\hline Variable name & Mean (MS) & SD (MS) & Mean (FS) & SD (FS) \\
\hline Deltaemp & 0.18 & 0.65 & NA & NA \\
Irish & 0.89 & 0.31 & 0.88 & 0.32 \\
Export & 0.34 & 0.47 & 0.32 & 0.47 \\
Profit & 0.77 & 0.43 & 0.73 & 0.44 \\
Union & 0.23 & 0.42 & 0.21 & 0.41 \\
Wage Bill & 0.35 & 0.19 & 0.35 & 0.19 \\
TotEmp98 & 69 & 192 & 67 & 179 \\
\hline
\end{tabular}

Notes: MS: matched sample; FS: full sample.

\section{Notes}

${ }^{1}$ The data we use were collected by the survey unit of the Economic and Social Research Institute. Copies of the questionnaires are available at $<$ http://www.nuim.ie/academic/economics/Donal/MWAGE.html>.

${ }^{2}$ It is important to recognize that the surveys looked at employment practices in Ireland in general. Firms were not asked directly about the minimum wage until the final page of the first survey.

${ }^{3}$ Response rates in the order of 50 per cent are quite common in firm-level studies.

${ }^{4}$ The 458 firms that appear only in the second wave were used in a separate study characterizing the Irish labour market. They do not enter the analysis presented in this paper.

${ }^{5}$ This implies a closure rate of approximately 5 per cent. In addition to these 50 firms, we can identify another 106 firms that no longer operated at the original address. It is possible that some of these firms may have gone out of business. Including all of these additional firms as closures gives an upper bound for the 
closure rate of 14.6 per cent. Data provided by Forfas (an agency responsible for the promotion of industrial development in Ireland) indicates that the official closure rate of this period was 13.6 per cent: this lies between our two estimates. When analysing the closure rate we include only the 50 firms that were actually identified as having closed down. The results do not change if we include the other 106 firms in our analysis as additional closures.

${ }^{6}$ For example, Neumark and Wascher (2000) suggest that the employment data from Card and Krueger's survey of fast-food establishments may contain significant measurement error. See Card and Krueger (2000) for a reply.

${ }^{7}$ We should note that if the measurement error in employment is not of the classical form then the test suggested by Neumark and Wascher is no longer valid.

${ }^{8}$ While we had significant control over the design of the survey, the implementation of the minimum wage itself was a sensitive issue that was carried out at government level. Thus it was not possible for us, as some have suggested, to alter the mechanism by which the minimum wage was introduced.

${ }^{9}$ Total non-agricultural employment in Ireland over this same period increased from 1.4 million to 1.58 million, an increase of approximately 13 per cent (Quarterly National Household Survey, First Quarter 2001, < http://www.cso.ie/ releasespublications/documents/labour_market/2001/qnhs_qtr12001.pdf>).

${ }^{10}$ The use of these controls accounts for the fall in sample size from 587 to 451 . For ease of comparison the results in columns (1) and (2) of Table 1 are based on the smaller sample. The results in column (1) are very similar if the full sample of 587 is used.

${ }^{11}$ The low $R^{2}$ reported in our regressions is typical of micro-studies of employment changes. For example, Machin et al. (2003) report a maximum $R^{2}$ of 0.15 for their employment change regression even after including individual- and firm-level characteristics. There are some variables in our data that do a better job of explaining employment fluctuations, such as the trend in sales over this same period. This variable is highly significant when included in the employment regression. However, our goal is to isolate the impact of the minimum wage on employment changes. Since part of this effect may work through a reduction in output (scale effect) we do not include the sales variable in the regression.

${ }^{12}$ For a more detailed discussion of the range of impact measures that have been used to estimate the impact of a NMW, see Lemos (2002).

${ }^{13} \mathrm{~A}$ small number of firms did not provide the information needed to construct EffectiveMW. As a result, the sample size falls further: from 451 to 444.

${ }^{14} \mathrm{We}$ have also estimated the employment equations in Table 3 including the binary measure of employment change in the earlier period as a control variable. This had only a small effect on the estimated coefficients, with the estimated mean employment effect changing from -0.29 to -0.28 and the median effect moving from -0.19 to -0.17 .

${ }^{15}$ As a final sensitivity check we restricted the analysis only to firms that said they would not have increased wages without the legislation. For these firms we can use variations in the proportion of the workforce that is low paid to identify the minimum wage effect. This analysis again reveals a negative relationship between employment changes and the bite of the minimum wage for those firms that were directly affected. Since this analysis is based only on those firms that we have classified as 'effective minimum wage firms', this relationship is purged of any ex post justification that may have affected the earlier results. Again, however, we must be wary of the small sizes involved in this latter analysis. 
${ }^{16}$ As noted by Machin et al. (2003, p. 173), this is analogous to using the minimum wage as an instrument in a first-stage wage regression of a structural model of the labour market.

${ }^{17}$ Further support for our finding that the minimum wage did not have a major effect on labour market outcomes over this period can be found in surveys carried out by the Small Firms Association (SFA), traditionally one of the greatest opponents of the minimum wage in Ireland. In these surveys the SFA ask its members to rank the problems facing small firms in Ireland at the time of the survey. It is interesting to note that in 2002 ( 2 years after the introduction of the minimum wage), the SFA did not deem it necessary to include a question concerning the minimum wage in its list of potential problems. A year later, in 2003, by which time the minimum wage had increased to $€ 6.35$, the minimum wage was included specifically as one of the potential problems but was ranked last in terms of importance by firms, below concerns such as traffic, red tape, and late payment from debtors (http://waterfordchamber.com/KieranCrowley). As an aside, insurance costs were ranked as the most important barrier facing firms in each of the most recent years.

\section{References}

Brown C. (1999) 'Minimum Wages, Employment and the Distribution of Income' in Handbook of Labor Economics, Vol. 3, Amsterdam: Elsevier Science.

Card D. and Kreuger A. (1995) Myth and Measurement: The New Economics of the Minimum Wage, Princeton: Princeton University Press.

Card, D. and Kreuger A. (2000) 'Minimum Wages and Employment: A Case Study of the Fast-food Industry in New Jersey and Pennsylvania: Reply', American Economic Review 90(5): 1397-1420.

Deere D., Murphy K. and Welch F. (1996) 'Examining the Evidence on Minimum Wages and Employment' in Kosters M. (ed.) The Effects of the Minimum Wage on Employment, Washington, DC: AEI Press: 26-54.

Dickens R. and Manning A. (2004a) 'Has the National Minimum Wage Reduced UK Wage Inequality?', Journal of the Royal Statistical Society (Series A) 167(4): 613-626.

Dickens R. and Manning A. (2004b) 'Spikes and Spill-overs: The Impact of the National Minimum Wage on the Wage Distribution in a Low Wage Sector', Economic Journal 114(494): C95-C101.

Dickens R., Machin S. and Manning A. (1999) 'The Effects of Minimum Wages on Employment: Theory and Evidence from Britain', Journal of Labor Economics 17: 1-22.

Fuchs V., Krueger A. and Poterba J. (1998) 'Economists' Views about Parameters, Values and Policies: Some Survey Results in Labor and Public Economics', Journal of Economic Literature XXXVI(3): 1387-1425.

Hamermesh D. (1993) Labor Demand, Princeton: Princeton University Press.

Lemos S. (2002) 'The Effect of the Minimum Wage on Wages and Employment in Brazil - A Menu of Minimum Wage Variables', Working Paper No. 02-02, University College London.

Li G. (1985) 'Robust Regression' in Hoaglin D., Mosteller F. and Tukey J. (eds.) Exploring Data Tables, Trends and Shapes, New York: John Wiley. 
Machin S. and Manning A. (1994) 'Minimum Wages, Wage Dispersion and Employment: Evidence from the UK Wages Council', Industrial and Labor Relations Review 47: 319-329.

Machin S. and Manning A. (1996) 'Employment and the Introduction of a Minimum Wage in Britain', Economic Journal 106: 667-676.

Machin S. and Wilson J. (2004) 'Minimum Wages in a Low-wage Labour Market: Care Homes in the UK', Economic Journal 114(494): C102-C108.

Machin S., Manning A. and Rahman L. (2003) 'Where the Minimum Wage Bites Hard: The Introduction of the UK National Minimum Wage to a Low Wage Sector', Journal of the European Economic Association 1(1): 154-180.

Neumark D. and Wascher W. (2000) 'Minimum Wages and Employment: A Case Study of the Fast-food Industry in New Jersey and Pennsylvania: Comment', American Economic Review 90(5): 1362-1396.

Report of the National Minimum Wage Commission (1998) Dublin: Government Publications Sale Office.

Stewart M. (2004) 'The Employment Effects of the National Minimum Wage', Economic Journal 114(494): C110-C116.

Teulings C. (2000) 'The Contribution of Minimum Wages to Increasing Wage Inequality’, Economic Journal 114(490): 801-833. 